\title{
PENGEMBANGAN INTERACTIVE E-BOOK BIDANG ASESMEN BAHASA \\ UNTUK MENGEMBANGKAN KOMPETENSI DAN KEMANDIRIAN MAHASISWA PROGRAM PENDIDIKAN BAHASA
}

\author{
Sri Wahyuni \\ FKIP Universitas Islam Malang \\ email: sriwy@yahoo.co.id
}

\begin{abstract}
Abstrak
Penelitian ini bertujuan menghasilkan model interactive electronic book (e-book) bidang asesmen bahasa untuk mengembangkan kompetensi dan kemandirian mahasiswa program pendidikan bahasa Indonesia. Penelitian menggunakan desain penelitian pengembangan dengan langkah-langkah: studi pendahuluan, perencanaan, dan pengembangan produk. Hasil penelitian sebagai berikut. Pertama, perangkat interactive e-book yang dikembangkan meliputi: Panduan Dosen, Petunjuk Mahasiswa, dan interactive e-book bidang Asesmen Bahasa. Kedua, hasil validasi ahli multimedia pembelajaran secara umum aspek produk yang dikembangkan sudah memadai (85\%). Ketiga, menurut ahli isi, secara umum isi produk yang dikembangkan sudah sangat memadai (94\%). Keempat,validasi perorangan menunjukkan secara umum mahasiswa menganggap produk ini sangat baik $(90 \%)$. Kelima, validasi kelas menunjukkan terdapat perbedaan yang signifikan antara nilai prates dan postes. Dengan demikian, interactive e-book yang dikembangkan efektif digunakan dalam pembelajaran asesmen bahasa.
\end{abstract}

Kata kunci: pengembangan, interactive e-book, asesmen bahasa

\section{DEVELOPING INTERACTIVE E-BOOKFOR LANGUAGE ASSESSMENT TO IMPROVE THE COMPETENCY AND AUTONOMY OF LANGUAGE EDUCATION PROGRAM STUDENTS}

\begin{abstract}
This study aims to produce an interactive electronic book (e-book) model for language assessment to develop the competency and autonomy of the students of the Indonesian language study program. The study employed a research and development procedure consisting of: a preliminary study, planning, and product development. The results of the study are as follows. First, the developed interactive e-book package consists of Lecturer's Manual, Student's Manual, and an interactive e-book on language assessment. Second, the results of the validation by the learning multimedia expert show that in general the product is appropriate ( $85 \%)$. Third, according to the subject matter expert, the contents of the product are very appropriate $(94 \%)$. Fourth, the individual validation shows that in general the students consider the product very good (90\%). Fifth, the class validation shows that there is a significant difference between the pretest score and the posttest score. Therefore, the developed interactive e-book is effective to be used in language assessment learning.
\end{abstract}

Keywords: development, interactive e-book, language assessment

\section{PENDAHULUAN}

Asesmen merupakan salah satu bidang dalam pembelajaran, yang bertujuan untuk menyimpulkan capaian hasil bela- jar seseorang. Menurut Bull et.al (2000:4), asesmen merupakan suatu proses pengumpulan informasi untuk membuat keputusan. Asesmen merupakan suatu pen- 
dekatan yang sistematis untuk mengumpulkan informasi mengenai belajar dan unjuk kerja peserta didik, dan biasanya didasarkan pada berbagai sumber bukti (Callison, 2007:1). Asesmen merupakan salah satu komponen penting dalam pembelajaran, yang semuanya harus dikuasai oleh mahasiswa sebagai calon guru.

Secara umum, mahasiswa program pendidikan bahasa merasa sulit belajar asesmen,sehingga banyak mahasiswa kurang tertarik belajar. Mahasiswa program pendidikan bahasa kurang tertarik terhadap materi asesmen disebabkan oleh beberapa aspek antara lain: kompleksitas materi dan model pembelajaran di kelas. Model pembelajaran yang secara umum digunakan dosen dalam pembelajaran adalah model klasikal dalam bentuk ceramah (secara dominan) dan latihan-latihan yang kurang terprogram. Pembelajaran yang demikian biasanya menjadikan mahasiswa kurang mandiri karena terlalu mengandalkan penjelasan dosen, dan latihan dikerjakan hanya kalau ditugaskan.

Menurut Kusuma (2011:49), belajar mandiri tidak berarti belajar sendiri. Hal yang terpenting dalam proses belajar mandiri adalah peningkatan kemauan dan keterampilan peserta didik dalam proses belajar tanpa bantuan orang lain, sehingga mereka tidak bergantung pada guru/dosen, teman, atau orang lain dalam belajar. Proses belajar mandiri memberi kesempatan peserta didik untuk mencerna materi ajar dengan sedikit bantuan guru/ dosen. Mereka mengikuti kegiatan belajar dengan materi ajar yang sudah dirancang khusus sehingga masalah atau kesulitan belajar sudah diantisipasi sebelumnya.

Untuk mengatasi kendala-kendala dalam pembelajaran yang masih konvensional tersebut, perlu dikembangkan model bahan pembelajaran yang memperhatikan perbedaan kemampuan mahasiswa, mendukung pembelajaran perseorangan dan mandiri, dan yang dapat memudahkan belajar mahasiswa. Menurut Dick \&
Carey (1990:72), bahan pembelajaran hendaknya merupakan bahan yang seluruhnya dapat dipelajari sendiri oleh peserta didik. Maksudnya, bahan tersebut dapat memberikan kesempatan pada peserta didik untuk mempelajari bahan tersebut tanpa bergantung pada penjelasan guru/ dosen. Pembelajaran yang baik juga akan mengaktifkan pembelajar dalam memberikan tanggapan, umpan balik dan juga mendorong peserta didik untuk melakukan praktik-praktik dengan benar. Dengan demikian, mengemas bahan ajar yang berkualitas sangat penting. Dengan tersusunnya bahan ajar yang berkualitas, proses pembelajarannya pun juga akan berkualitas. Bahan ajar merupakan unsur yang menentukan keberhasilan mahasiswa belajar, oleh karena itu bahan ajar harus dikemas dengan tepat.

Berdasarkan permasalahan tersebut, dalam penelitian ini dikembangkan bahan perkuliahan pada materi asesmen bidang bahasa dalam bentuk interactive electronic book (e-book). Materi ini dikembangkan agar mahasiswa prodi pendidikan bahasa Indonesia memiliki kompetensi yang baik di bidang asesmen, di samping juga untuk melatih mahasiswa belajar secara mandiri. Mahasiswa tidak hanya menjadi penerima yang pasif melainkan juga menjadi penentu pembelajaran bagi dirinya sendiri. Pembelajaran yang demikian diharapkanakan memberikan motivasi yang lebih tinggi karena interactive e-book selalu dikaitkan dengan kesenangan, permainan, dan kreativitas. Melalui model bahan dan sekaligus asesmennya yang bersifat interaktif akan membuat mahasiswa belajar tanpa beban dan tanpa tekanan karena beragamnya penyajian materi dan asesmen yang menyenangkan. Rose dan Nicholl (2006:4) menyatakan asesmen pembelajaran sebaiknya mampu menciptakan situasi yang mengasyikkan sehingga peserta didik termotivasi belajar dengan cepat tanpa merasa ada beban, yang ini terwadahi dalam produk 
ini. Melalui produk ini, proses dan hasil belajar sekaligus dapat dinilai. Dengan demikian, asesmen yang dilakukan bersifat otentik, yang mengukur proses dan hasil belajar mahasiswa secara menyeluruh.

Tujuan penelitian ini adalah menghasilkan model interactive electronic book (e-book) bidang Asesmen Bahasa yang dapat mengembangkan kompetensi dan kemandirian mahasiswa program pendidikan bahasa Indonesia. Penelitian ini dilaksanakan selama dua tahun. Pada tahun pertama, penelitian bertujuan mengidentifikasi kondisi awal dan mengembangkan tiga perangkat bahan, yaitu (1) Panduan Dosen, (2) Petunjuk Mahasiswa, dan (3) Interactive E-book bidang Asesmen Bahasa. Pada tahun kedua, penelitian bertujuan untuk memvalidasi produk yang meliputi (1) validasi ahli, (2) validasi perorangan, dan (3) validasi kelas.

Pengembangan model interactive electronic book (e-book) bidang asesmen bahasa ini penting dilakukan karena beberapa hal berikut. Pertama, ada perubahan budaya belajar mahasiswa dari yang klasikal ke individual/mandiri. Kedua, asesmen menjadi suatu pembelajaran yang menarik, memudahkan belajar, dan tidak membosankan. Ketiga, dapat mengatasi kekurangan bahan dan rujukan tentang asesmen yang secara khusus digunakan dalam bidang bahasa, yang dengan mudah dapat dipahami oleh para mahasiswa. Keempat, dapat mengatasi kekurangan sumber pembelajaran asesmen bidang bahasa yang sengaja dirancang secara sistematis dengan berpegang pada prinsip-prinsip pengembangan pembelajaran. Kelima, materi pembelajaran berbentuk elektronik akan memudahkan dosen dan mahasiswa dalam proses pembelajaran karena bahan yang dikembangkan tersebut sudah merupakan bahan yang siap pakai. Keenam, mahasiswa dapat mengukur kemampuannya sendiri karena sifat penilaiannya yang interaktif dan otentik. Model penilaian asesmen otentik seperti ini dapat memberikan kesempatan luas pada mahasiswa untuk menunjukkan apa yang telah mereka pelajari selama proses pembelajaran (Johnson, 2002:165). Ketujuh, berperan dalam mengembangkan diri mahasiswa, terutama untuk mengembangkan potensi dan kemandiriannya. Para mahasiswa dapat mengikuti program pembelajaran sesuai dengan kecepatan dan kemampuan sendiri, lebih banyak belajar mandiri, dapat mengetahui hasil belajar mandiri, dan dapat menekankan penguasaan bahan pelajaran secara optimal sehingga kompetensinya meningkat. Kedelapan, belajar asesmen dalam bentuk e-book merupakan bentuk belajar yang sangat efektif dan efisien di zaman sekarang ini, karena harga kertas melambung tinggi dan banyak kemungkinan cepat rusak.

\section{METODE}

Dilihat dari proses dan tahapannya, penelitian ini termasuk pengembangan. Model pengembangan yang digunakan adalah model pengembangan sistem yang mencakup langkah-langkah: studi pendahuluan, perencanaan dan pengembangan produk. Studi pendahuluan meliputi kegiatan, (1) mengidentifikasi kebutuhan belajar mahasiswa dan dosen, dan (2) mengidentifikasi karakteristik mahasiswa. Perencanaan dan pengembangan produk meliputi kegiatan (1) mengidentifikasi tujuan umum pembelajaran, (2) melakukan analisis pembelajaran, (3) merumuskan tujuan khusus, (4) pengembangan strategi pembelajaran interaktif, dan (5) penyusunan perangkat interacive e-book, yang meliputi petunjuk dosen, petunjuk mahasiswa, dan bahan pembelajaran berupa interacive e-book. Alur model pengembangan dijelaskan dalam Bagan 1, Bagan 2, dan Bagan 3.

Subjek coba penelitian ini adalah mahasiswa Pendidikan Bahasa dan Sastra Indonesia FKIP Unisma sebagai pemakai produk. 


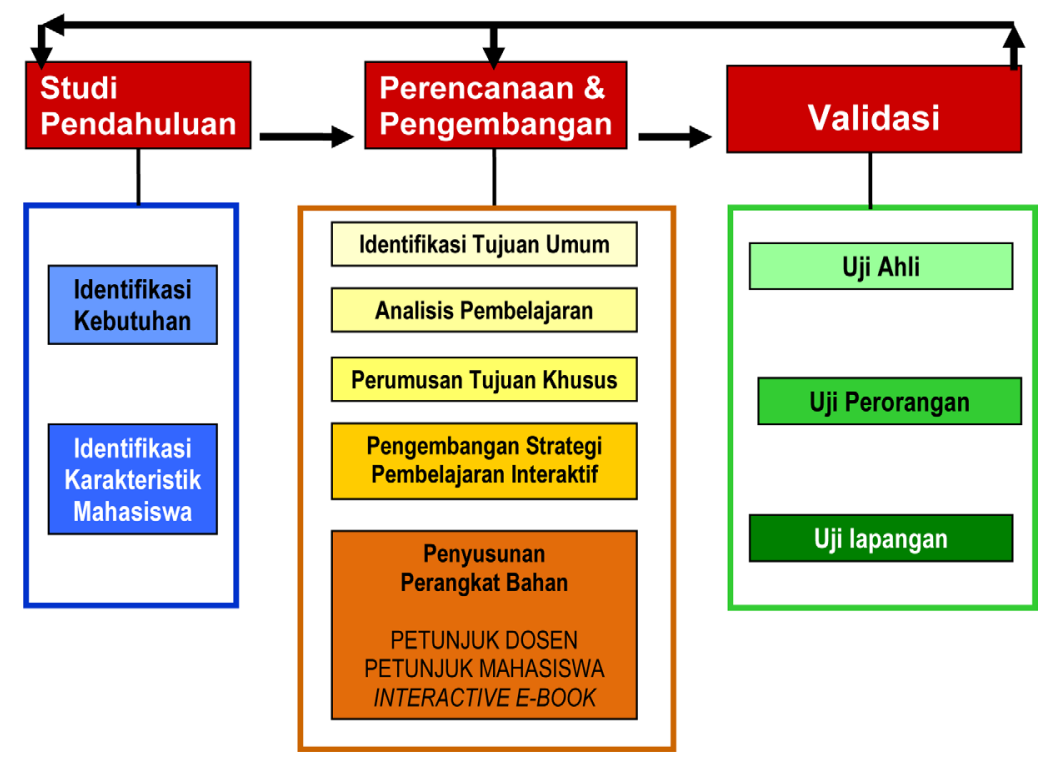

Bagan 1. Model Pengembangan Penelitian

Pengumpulan data dalam penelitian ini dilakukan dengan empat teknik, yakni: (1) angket,(2) telaah pustaka, (3) observasi, dan (4) tes. Sejalan dengan teknik pengumpulan data yang digunakan, dalam penelitian ini dikembangkan intrumen (1) angket untuk mengumpulkan data analisis kebutuhan dan karakteristik mahasiswa, angket untuk uji ahli, dan uji perorangan; (2) jaring-jaring materi hasil telaah pustaka, yang terkait dengan materi asesmen bidang bahasa sebagai bahan interactive e-book; (3) panduan observasi terhadap pelaksanaan uji coba produk di lapangan, (4) tes untuk mengukur efektivitas produk yang dikembangkan. Data dalam penelitian ini dianalisis dengan dua macam teknik. Pertama, data dianalisis secara kualitatif khususnya untuk data dari hasil telaah pustaka, angket analisis kebutuhan, karakteristik mahasiswa, dan hasil observasi. Kedua, data dianalisis secara kuantitatif, khususnya untuk data hasil validasi ahli, perorangan, dan hasil uji coba lapangan. Teknik yang digunakan untuk menganalisis data validasi ahli dan perorangan adalah statistik deskriptif, sedangkan teknik yang digunakan untuk menganalisis data hasil uji coba lapangan adalah uji-t sampel berpasangan.

\section{HASIL DAN PEMBAHASAN}

Hasil penelitian dideskripsikan berdasarkan langkah pengembangan yang mencakup (1) hasil studi pendahuluan, (2) perencanaan dan pengembangan produk, dan (3) validasi produk.

\section{Hasil Studi Pendahuluan}

Studi pendahuluan dilakukan untuk mengumpulkan data analisis kebutuhan dan identifikasi karakteristik mahasiswa. Kebutuhan (need) adalah kesenjangan antara apa yang diharapkan dengan kondisi yang sebenarnya. Analisis kebutuhan digunakan sebagai alat untuk mengidentifikasi masalah guna menentukan tindakan yang tepat. Dalam penelitian ini, analisis kebutuhan dilakukan untuk memperoleh informasi dari mahasiswa tentang perkuliahan asesmen bahasa selama ini, apakah ada masalah, apa penyebabnya, apakah cara yang digunakan dosen selama ini disukai dibandingkan dengan dosen yang lain, dan apakah jalan keluar penyediaan materi dalam bentuk e-book merupakan sesuatu yang mereka butuhkan, dan sebagainya. Dengan demikian, analisis kebutuhan yang diidentifikasi meliputi identifikasi kebutuhan normatif, kebutuhan komparatif, kebutuhan yang 
HASIL PENELITIAN/KAJIAN ILMIAH YANG LALU (Wahyuni, 2003-2010)

(Pengembangan modul, pengembangan perangkat asesmen, pengembangan bahan yang telah direformasi)

TAHUN I:

STUDI PENDAHULUAN $\quad \rightarrow \quad$ Identifikasi Kebutuhan

Identifikasi Karakteristik Mahasiswa

PERENCANAAN DAN PENGEMBANGAN

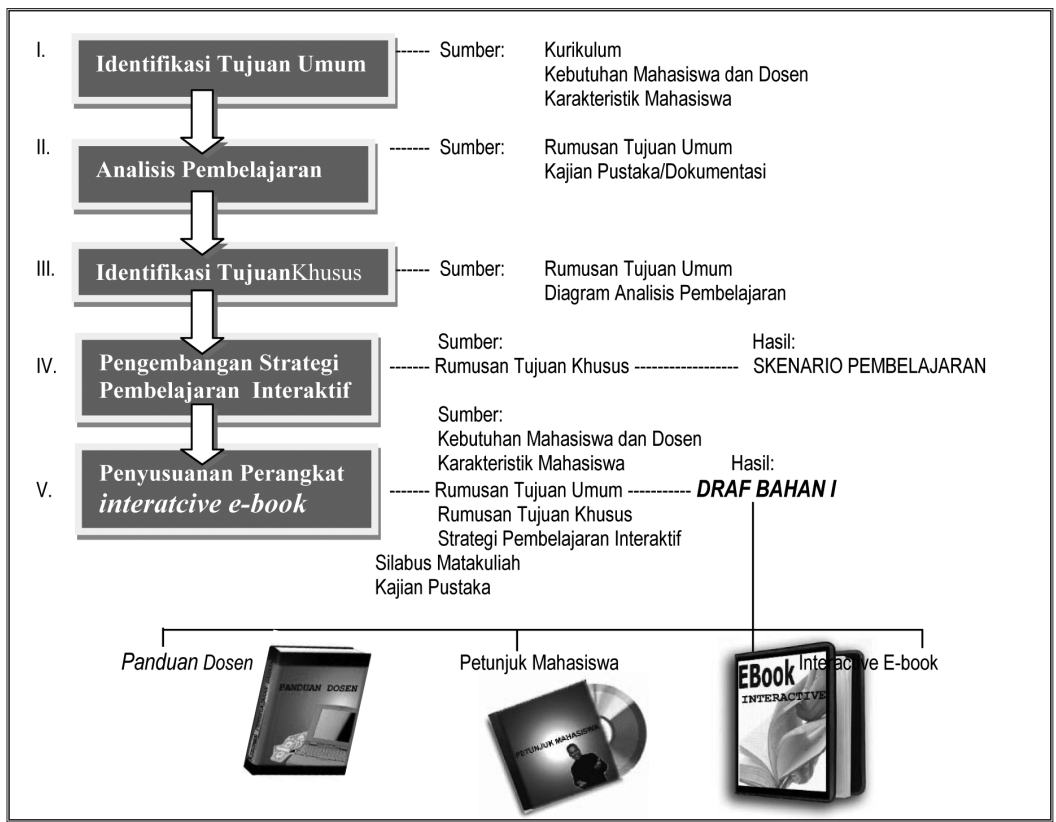

Bagan 2. Langkah-langkah Pengembangan Penelitian Tahun 1

TAHUN II: VALIDASI

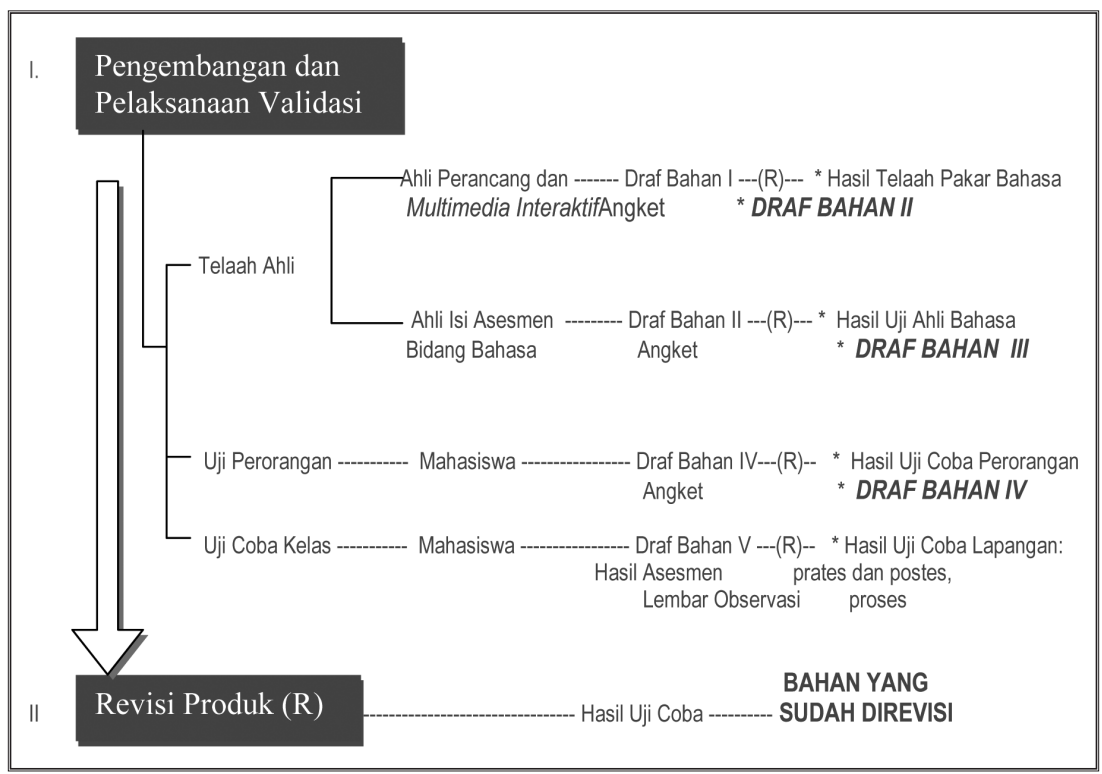

Bagan 3. Langkah-langkah Pengembangan Penelitian Tahun 2 
dirasakan, dan kebutuhan masa depan.

Hasil studi pendahuluan menunjukkan: (1) beberapa masalah yang dijumpai dalam pembelajaran asesmen antara lain bahan pembelajarannya yang banyak dan padat sehingga beban belajar mahasiswa menjadi sangat banyak, (2) model pembelajaran yang monoton, yaitu dominan penjelasan dosen dan mengerjakan latihan, begitu seterusnya, (3) pembelajaran tidak banyak memanfaatkan media pembelajaran sehingga kurang ada variasi, (4) kurang adanya umpan balik terhadap tugas yang telah dikerjakan oleh mahasiswa. Berdasarkan kondisi ini, secara umum mahasiswa berpendapat bahwa memang perlu dikembangkan bahan pembelajaran interaktif yang banyak melibatkan mereka dalam pembelajaran, dan mengurangi peran dosen yang sangat dominan. Hal ini sesuai dengan pendapat Gebhard (2000:53), bahwa salah satu faktor yang mendukung terciptanya aktivitas pembelajaran yang interaktif, yaitu adanya pengurangan peran sentral pengajar. Di antara sekian banyak media pembelajaran, yang paling menarik bagi mereka adalah penggunaan komputer dalam pembelajaran, apalagi kalau dihubungkan dengan internet.Tetapi dalam pelaksanaannya nantinya mereka masih sangat perlu kehadiran dosen, sehingga pembagian peran dosen dan materi menjadi jelas. Berdasarkan studi pendahuluan tersebut, maka pengembangan produk interactive $e$-book ini cocok dan memang dibutuhkan oleh mahasiswa.

Secara umum, karakteristik mahasiswa cukup baik sehingga sangat memungkinkan produk penelitian ini digunakan pada mereka. Sebagai contoh, mereka sangat menyenangi bidang yang mereka pelajari saat ini sehingga mereka cukup bersemangat untuk mengikutinya (73\% sangat setuju). Keinginan belajar mahasiswa juga cukup tinggi (61,40\% sangat setuju) sehingga ini akan mempermudah dalam proses pembelajaran. Mereka juga sangat menyenangi pembelajaran yang bervariasi $(80,70 \%)$, dan juga sangat menyenangi perkuliahan yang memanfaatkan teknologi informasi seperti komputer dan atau internet (70,18\%). Mereka cukup senang dengan model pembelajaran interaktif melalui komputer (56,14\%) meskipun ditemui juga yang kurang suka dengan pembelajaran interaktif dengan komputer $(1,75 \%)$.

Sikap, minat, dan motivasi mahasiswa secara umum dalam belajar cukup baik, yang tentu saja ini akan sangat menunjang berhasilnya produk yang akan dikembangkan. Karakteristik mahasiswa yang perlu mendapat perhatian adalah pada kemampuan mereka yang beragam dalam mengoperasikan komputer. Untuk mengatasi ini, perlu diberikan bekal kemampuan mahasiswa khususnya dalam mengoperasikan komputer dengan internet. Karakteristik yang dilihat dari sikap mahasiswa yang sangat mendukung dikembangkannya produk e-book bidang asesmen bahasa akan memudahkan dan sangat membantu peneliti dalam menyusun dan menerapkan produk pengembangan.

Dari data analisis kebutuhan dan karakteristik mahasiswa tersebut, dapat dimaknai dukungan terhadap dikembangkannya produk interactive e-book asesmen bidang bahasa disajikan pada Grafik 1.

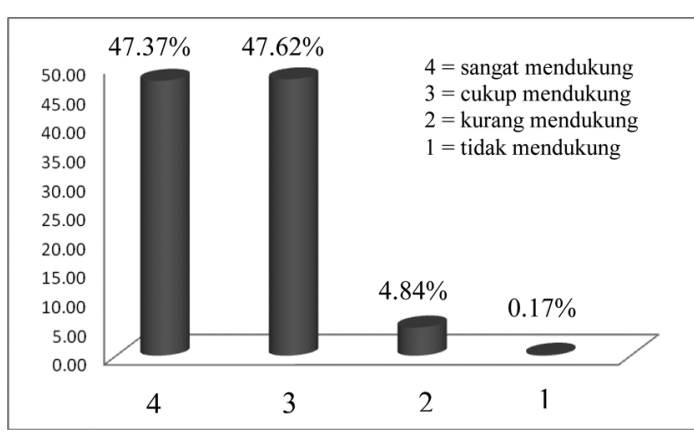

Grafik 1. Hasil Analisis Karakteristik dan Kebutuhan Mahasiswa 
Jadi sebagian besar mahasiswa cukup mendukung $(47,62 \%)$, sebagian lagi sangat mendukung $(47,37 \%)$, dan sebagian kecil $(4,84 \%)$ kurang mendukung serta 0,17\% tidak mendukung. Ketika dikonfirmasi pada mereka yang kurang atau tidak mendukung, ternyata alasannya mereka sebagian besar kurang menguasai IT, sehingga mereka takut tidak bisa mengikuti perkuliahan dengan baik.

Data seperti ini sangat penting diketahui oleh peneliti. Menurut Dick \& Carey (1990), seorang pengembang perlu mengenali ciri-ciri khusus tertentu yang dimiliki mahasiswa yang memang perlu dipertimbangkan dalam merancang kegiatankegiatan pembelajaran (termasuk pengembangan interactive e-book asesmen bahasa). Menurut Sadiman (1996:103), dengan melakukan identifikasi karakteristik mahasiswa, berarti akan diketahui pengetahuan dan keterampilan awal mereka sebelum mengikuti kegiatan pembelajaran dengan bahan yang akan dikembangkan.

Berangkat dari hasil analisis kebutuhan dan karakteristik mahasiswa tersebut, berarti cukup alasan dikembangkannya model interactive e-book asesmen pembelajaran bahasa. Meskipun kelihatannya ada kendala sedikit pada mahasiswa yang kurang menguasai teknologi komputer, tapi ini dapat diatasi dengan pengembangan $e$-book yang tidak terlalu rumit pengoperasiannya.

Data yang terkumpul dari kegiatan analisis kebutuhan dan identifikasi karakteristik mahasiswa ini selanjutnya digunakan sebagai dasar dalam perencanaan dan pengembangan produk.

\section{Hasil Perencanaan Produk}

Pada perencanaan produk, langkah pertama yang dilakukan adalah menentukan tujuan umum pembelajaran. Tujuan umum ini dirumuskan dari Satuan Acara Perkuliahan (SAP) dan hasil studi pendahuluan. Secara umum, tujuan perkuliahan ini adalah mahasiswa memiliki pemaha- man yang memadai tentang prinsip dan prosedur melakukan asesmen pembelajaran bahasa, dan dapat menerapkan prinsip serta prosedur tersebut dalam melakukan asesmen pembelajaran bahasa Indonesia.

Kedua, dilakukan analisis materi pembelajaran asesmen bahasa. Analisis pembelajaran merupakan proses penjabaran perilaku umum menuju ke perilaku khusus yang tersusun secara logis dan sistematis. Analisis pembelajaran ini menghasilkan seperangkat prosedur yang diterapkan dalam pembelajaran asesmen bahasa. Analisis pembelajaran berupa identifikasi langkah-langkah yang relevan bagi penyelenggaraan tujuan dan kemampuankemampuan subordinat yang dibutuhkan oleh mahasiswa untuk mencapai tujuan. Analisis pembelajaran ini menghasilkan sembilan topik pembelajaran, yaitu (1) Konsep Dasar Asesmen, (2) Teknik Asesmen dalam Pembelajaran Bahasa, (3) Asesmen Keterampilan Berbahasa dan Bersastra, (4) Penyusunan Tes Bahasa, (5) Penyusunan Asesmen Bahasa Nontes, (6) Validitas Asesmen, (7) Reliabilitas Asesmen, (8) Analisis Butir Soal Asesmen Bidang Bahasa, dan (9) Penilaian Hasil Belajar Bahasa. Salah satu contoh hasil analisis materi pada topik Reliabiltas Asesmen disajikan pada Bagan 4.

Ketiga, merumuskan tujuan khusus pembelajaran asesmen bahasa. Tujuan ini dirinci dari tujuan umum dan hasil analisis pembelajaran. Dalam setiap tujuan dirumuskan menjadi beberapa tujuan khusus sejalan dengan analisis pembelajaran yang telah dikembangkan. Contoh salah satu rumusan tujuan khusus yang dikembangkan berdasarkan tujuan umum disajikan pada Bagan 5.

Keempat, mengembangkan strategi pembelajaran interaktif. Pembelajaran dengan multimedia tetap menganggap kehadiran dosen penting. Oleh karena itu pembelajaran dirangcang dengan baik dengan tetap melibatkan kegiatan dosen dan mahasiswa. Strategi interaktif dipi- 
lih karena sesuai dengan produk yang dikembangkan yaitu interactive e-book. Pada pengembangan strategi pembelajaran ini disusun langkah-langkah pembelajaran mulai awal hingga akhir perkuliahan, yang dikembangkan dengan prinsip pembelajaran komunikatif.

\section{Hasil Pengembangan Produk}

Berdasarkan hasil langkah-langkah perencanaan produk, selanjutnya dilakukan proses penyusunan draf perangkat interactive e-book, yang meliputi panduan dosen, petunjuk mahasiswa, dan bahan pembelajaran berupa interactive e-book.
Panduan Dosen berisi arahan kepada dosen pengampu matakuliah bagaimana menggunakan interactive e-book yang dikembangkan, yang berisi komponen: (1) kajian teoritis tentang asesmen bidang bahasa dan (2) petunjuk penggunaan interactive e-book (Gambar 1). Petunjuk Mahasiswa berisi arahan kepada mahasiswa bagaimana cara menggunakan interactive e-book dan berisi tentang pokok-pokok bahasan yang harus dipelajari dan jabaran kemampuan yang didukung setelah selesai mengikuti program pembelajaran dengan bahan pembelajaran asesmen bidang bahasa melalui interactive e-book tersebut.

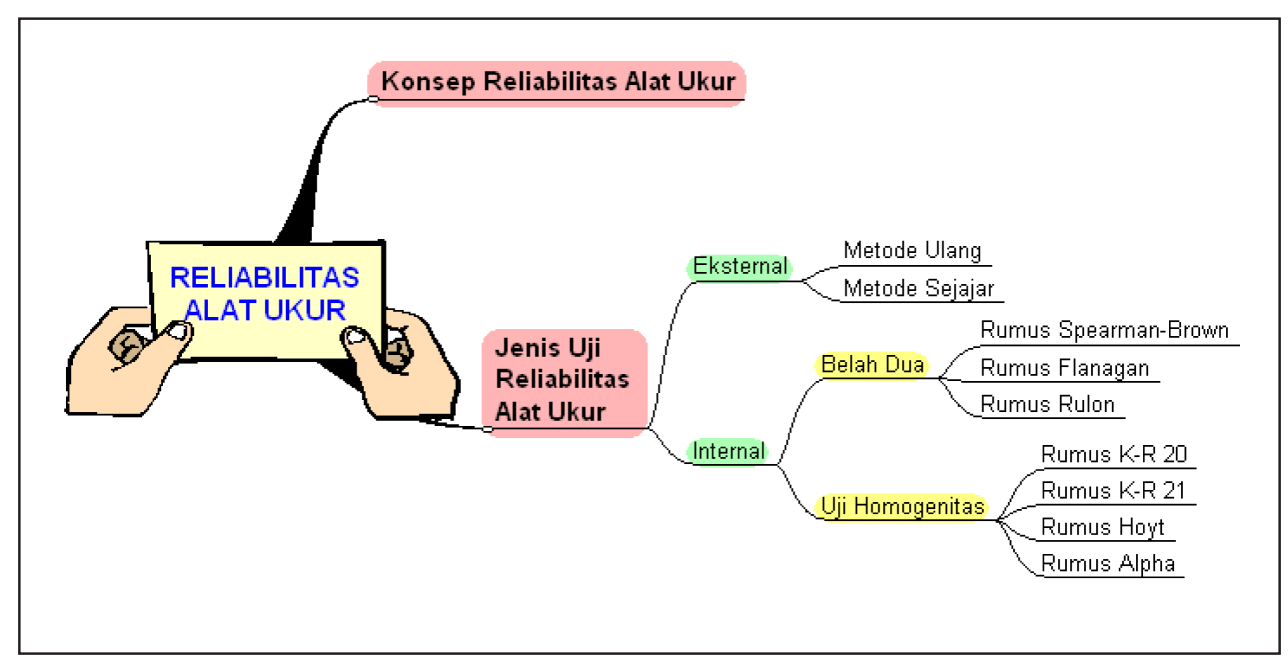

Bagan 4. Contoh Analisis Pembelajaran pada Topik Reliabilitas

Tujuan Umum 5:

Mahasiswa mampu menyusun asesmen bahasa nontes secara beragam

Tujuan Khusus:

1) Mahasiswa dapat menjelaskan penggunaan masing-masing jenis asesmen nontes yang meliputi (1) asesmen kinerja, (2) portofolio, (3) proyek, (4) penilaian diri, (5) penilaian sejawat, (6) penilaian produk, dan (7) penilaian sikap.

2) Mahasiswa mampu menyusun instrumen dan rubrik asesmen nontes yang meliputi (1) asesmen kinerja, (2) portofolio, (3) proyek, (4) penilaian diri, (5) penilaian sejawat, (6) penilaian produk, dan (7) penilaian sikap.

Bagan 5. Contoh Rumusan Tujan Khusus pada Topik Penyunan Asesmen Bahasa Nontes 


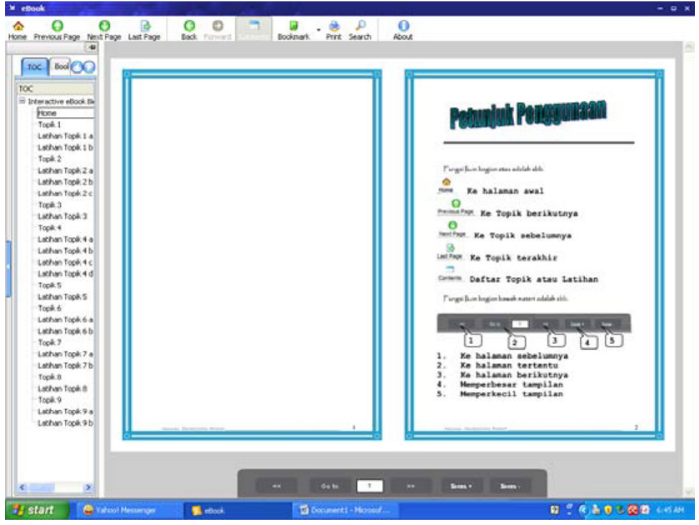

Gambar 1. Halaman Petunjuk Penggunaan

Produk ketiga penelitian ini adalah Interactive E-book Asesmen Bidang Bahasa. Produk ini berisi sejumlah subkomponen bahan yang dikemas dalam bentuk interactive e-book. E-book ini dikembangkan dari program sebagai berikut. Pertama, e-bookini dikembangkan dengan EbookMaker 2.2. Sofware ini produk dari Antsoft 2005-2008.

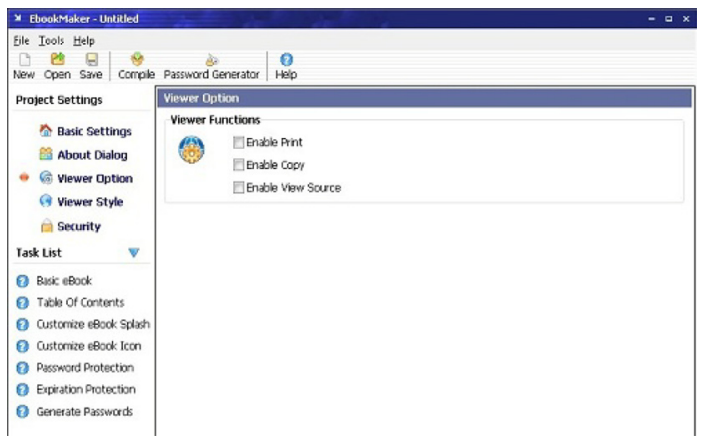

Gambar 2. Program E-book Maker

E-book Maker adalah perangkat lunak profesional kompiler (Gambar 2). Dikatakan demikian karena software ini dapat mengkompilasi semua file HTML dan gambar mereka termasuk, JavaScript, Flash, MP3, dan file video dalam folder tertentu ke file EXE. File tersebut mudah untuk didistribusikan melalui CDROM, Email Internet, dan Ebook menggunakan Internet Explorer untuk menampilkan halaman HTML. Pembaca tidak perlu mengin- stal perangkat lunak lain untuk membuka Ebook untuk membaca. Sederhana dan mudah digunakan, Ebook Maker menyediakan berbagai fitur untuk memenuhi setiap kebutuhan penulis Ebook. Software ini memiliki persyaratan sistem windows 98/ME/2000/XP/2003/Vista.

Kedua, e-book ini dikembangkan dengan software hot potatoes. Software ini banyak berisi latihan interaktif seperti Jcloze, Jmatch, Jquiz, Jcross, Jmix, dan The Masher (Gambar 3).

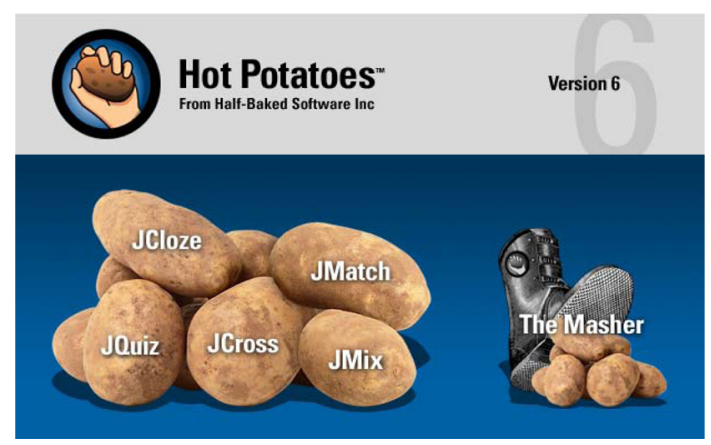

Gambar 3. Program Hot Potatoes

Ketiga, pengembangan $e$-book ini juga menggunakan CodeBox, yang bisa mengkonversi PDF ke Flash Flip secara online (Gambar 4).

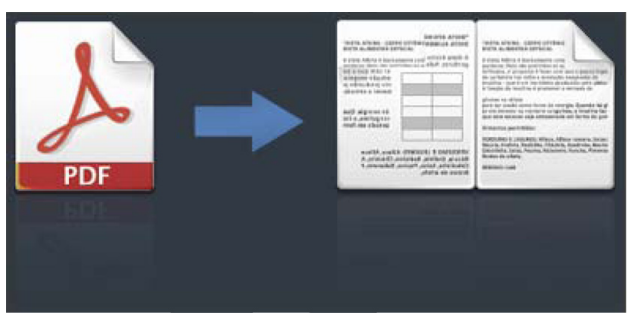

Gambar 4. Code Box: mengkonversi PDF ke Flash Online

CodeBox adalah layanan web yang memungkinkan kita untuk dengan mudah mengkonversi file PDF dalam Flash (SWF), karena dapat mempublikasikan suatu halaman web. Hal ini hanya diperlukan untuk memilih file PDF, melakukan beberapa pengaturan (jika diinginkan) dan men-download file arsip zip yang flash, html dan file lainnya. 
Keempat, dalam pengembangan $e$ book ini digunakan Open Office 3.0. Open Office Versi 3.0 sudah diluncurkan pada bulan Oktober 2008 dan mendapat sambutan yang sangat baik dari para pengguna. Versi terbaru dari Open Office ini memiliki performance yang jauh lebih baik daripada versi sebelumnya ditambah berbagai peningkatan kemampuan kompatibilitas dan interoperabilitas dengan format dokumen (Gambar 5).

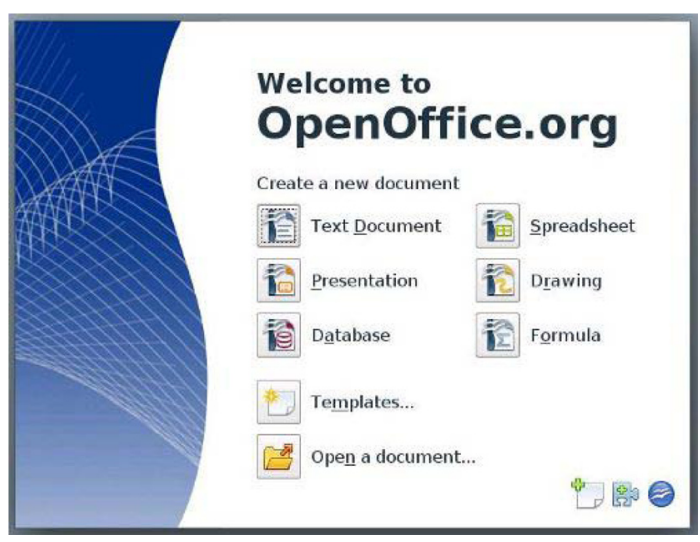

Gambar 5. Open Office 3.0

Selain disusun dengan software yang tepat, bahan dalam e-book ini ditata sedemikian rupa agar materi asesmen bidang bahasa lebih mudah dikuasai oleh mahasiswa. Bahan tersebut dikemas dalam satu perangkat bahan dengan beberapa topik, yang masing-masing topik bahan meliputi: (1) Peta Konsep, (2) Tujuan, (3) Pengantar, (4) Uraian Materi, dan (5) Latihan Interaktif. Peta konsep diberikan agar mahasiswa memperoleh gambaran umum dulu apa yang dipelajari dalam suatu topik. Dengan dirumuskannya tujuan, arah pembelajaran menjadi jelas dan tidak menyimpang. Selanjutnya disusun uraian materi yang cukup rinci, dan diakhiri dengan latihan interaktif berupa latihan yang dikerjakan secara langsung oleh siswa saat itu juga. Contoh e-book yang dikembangkan disajikan pada Gambar 6, 7, 8, dan 9.

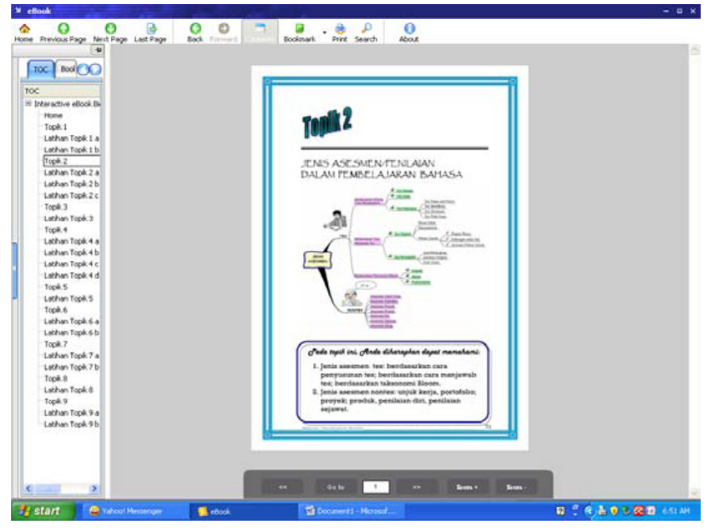

Gambar 6. Contoh Halaman Peta Konsep

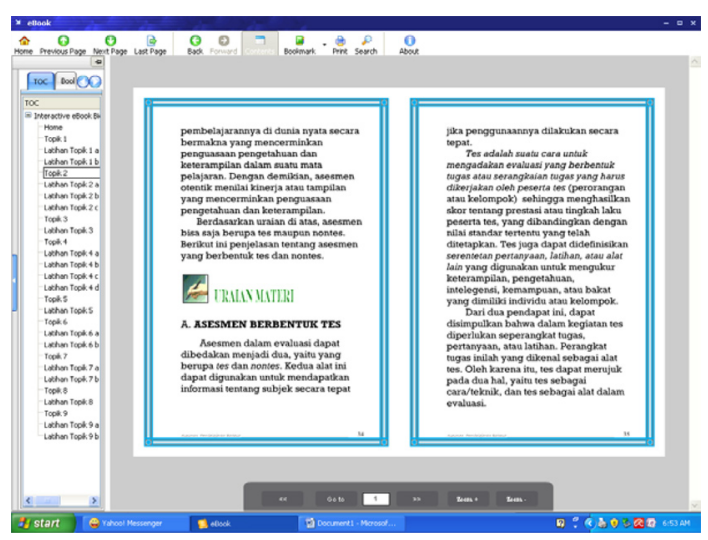

Gambar 7. Contoh Halaman Uraian Materi

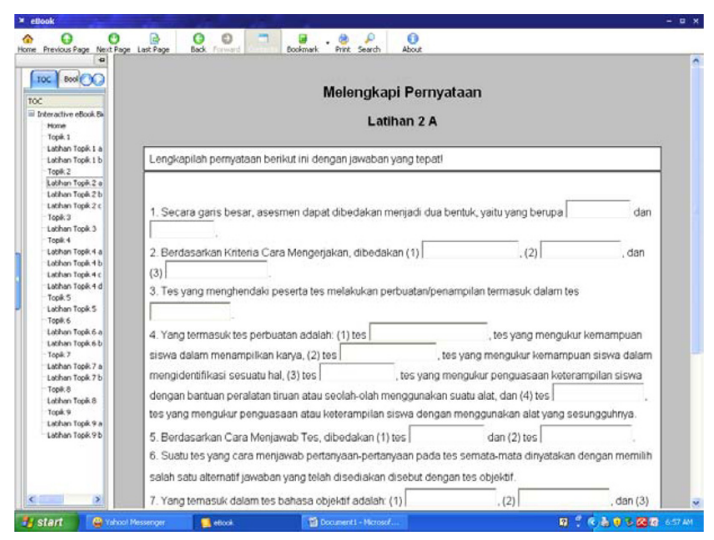

Gambar 8. Contoh Halaman Latihan Soal Melengkapi 


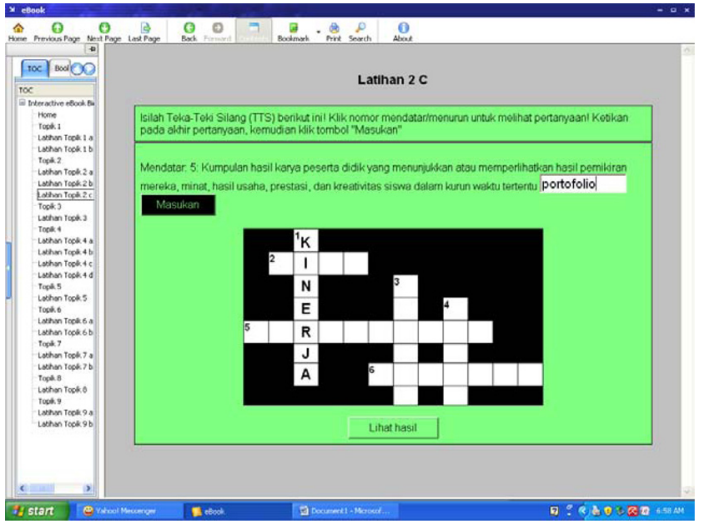

Gambar 9. Contoh Halaman Latihan Soal Teka-teki Silang

\section{Validasi Produk}

Pada tahun kedua, penelitian bertujuan memvalidasi produk yang dihasilkan pada tahun pertama. Validasi meliputi: (1) validasi ahli, (2) validasi perorangan atau individu, dan (3) validasi kelas.

\section{Validasi Ahli Perancang dan Multimedia Pembelajaran}

Menurut perancang dan multimedia pembelajaran, secara umum aspek produk penelitian yang dikembangkan sudah memadai $(85 \%)$. Ini berarti, e-book yang dikembangkan layak digunakan dalam pembelajaran. Rancangan dan multimedia yang dikembangkan sudah memenuhi persyaratan media pembelajaran yang baik. Dari lima belas aspek yang dinilai, ada dua aspek yang dinilai cukup, yaitu aspek kesembilan dan kesebelas. Pada aspek kesembilan yaitu kinteraktifan latihan yang diberikan dalam e-book, ahli menilai cukup (63\%). Alasan ahli dalam hal ini adalah, ada beberapa soal essai yang dimasukkan sehingga nilai interaktifnya tidak ada. Aspek ini selanjutnya menjadi catatan untuk revisi produk. Pada aspek kesebelas yaitu jenis huruf yang digunakan, ahli menilai cukup (63\%). Alasan ahli dalam hal ini adalah adanya jenis huruf yang tidak konsisten antara topik, latihan, dan antartopik, Aspek ini juga menjadi catatan untuk revisi produk.
Validasi Ahli Asesmen Pembelajaran Bahasa

Menurut ahli, secara umum isi yang terkandung dalam interactive e-book bidang asesmen bahasa sudah sangat memadai (94\%). Ini berarti, apa yang dibahas dalam e-book secara keilmuan dapat dipertanggungjawabkan kebenarannya. Tujuh aspek (Konsep Dasar, Jenis Asesmen dalam Pembelajaran Bahasa, Asesmen Keterampilan Berbahasa dan Bersastra, Penyusunan Asesmen Bahasa Nontes, Validitas Alat Ukur dalam Asesmen Pembelajaran Bahasa, Reliabilitas Alat Ukur dalam Asesmen Bahasa, dan Analisis Butir Soal dalam Asesmen Bahasa) dinilai sangat memadai (100\%), dan dua aspek (Penyusunan Tes Bahasa dan Pengolahan Skor Mentah dalam Nilai Standar) dinilai cukup memadai (75\%). Saran ahli pada Penyusunan Tes Bahasa, sebaiknya dalam setiap langkah disertai dengan contoh-contoh supaya pemahaman mahasiswa semakin baik. Pada materi Pengolahan Skor Mentah dalam Nilai Standar, ahli menyarankan adanya penggabungan dua jenis pedoman penilaian. Beberapa saran ini akan menjadi catatan untuk revisi produk.

\section{Validasi Perorangan/Individu}

Secara umum, mahasiswa sangat menyetujui semua pernyataan yang dikemukakan dalam angket (90\%). Ini berarti, mahasiswa sangat sangat senang, faham, dan mudah menggunakan produk penelitian ini.

\section{Validasi Kelas}

Validasi kelas terhadap produk penelitian dilakukan pada tujuh puluh mahasiswa. Rancangan yang digunakan dalam uji validasi adalah quasi eksperimental atau eksperimental semu dengan jenis pratest - postest design. Hasil prates dan postes keempat kelas tersebut adalah sebagai berikut.

Data penelitian menunjukkan bahwa terjadi peningkatan skor dari prates ke postes. Rata-rata nilai postes siswa $=$ 
79.44, dengan $\mathrm{SD}=7.820$, dan $\mathrm{SEM}=0.935$. Berdasarkan hasil analisis data diketahui, $\mathrm{t}=26.153$ dengan probabilitas $(\mathrm{p})=0.000$. Dengan demikian dapat disimpulkan, bahwa terdapat perbedaan yang signifikan antara nilai prates dan postes karena $\mathrm{p}<0.01$. Jadi, interactive e-book yang dikembangkan dalam penelitian ini efektif digunakan dalam pembelajaran asesmen bahasa.

\section{SIMPULAN}

Studi Pendahuluan dalam penelitian ini meliputi kegiatan mengidentifikasi kebutuhan dan karakteristik mahasiswa. Hasil studi pendahuluan menunjukkan, mahasiswa lebih menyenangi perkuliahan yang interaktif, yang banyak melibatkan dirinya dalam pembelajaran. Pembelajaran, yang paling menarik bagi mahasiswa adalah pembelajaran yang memanfaatkan komputer, apalagi kalau dihubungkan dengan internet.

Perencanaan dan pengembangan produk meliputi kegiatan mengidentifikasi tujuan umum pembelajaran, melakukan analisis pembelajaran, merumuskan tujuan khusus, pengembangan strategi pembelajaran interaktif, dan penyusunan perangkat interacive e-book. Produk yang dikembangkan berupa (1) panduan dosen, (2) petunjuk mahasiswa, dan (3) interactive $e$-book asesmen bidang bahasa, yang dirancang dan dikembangkan secara sistematis dengan berpegang pada prinsip-prinsip pengembangan pembelajaran.

Hasil uji validasi produk menunjukkan sebagai berikut. Menurut perancang dan multimedia pembelajaran, secara umum aspek produk penelitian yang dikembangkan sudah memadai (85\%). Menurut ahli isi, secara umum isi yang terkandung dalam interactive e-book bidang asesmen bahasa sudah sangat memadai (94\%). Validasi perorangan menunjukkan, secara umum, mahasiswa sangat senang, mudah memahami, dan mudah mengoperasikan e-book yang dikembangkan (90\%). Validasi kelas menunjukkan, interactive e-book yang dikembangkan dalam pembelajaran efektif digunakan dalam pembelajaran asesmen bahasa.

\section{UCAPAN TERIMA KASIH}

Artikel ini diangkat dari hasil laporan penelitian yang dibiayai oleh dana Penelitian Hibah Bersaing Dikti Tahun 2011-2012. Oleh karena itu, ucapan terima kasih disampaikan pada Ditlitabmas Dikti selaku penyandang dana, LPPM Universitas Islam Malang, Ketua Jurusan PBSI Unisma, dan mahasiswa semester lima tahun pelajaran 2011/2012. Selanjutnya, ucapan terima kasih disampaikan kepada dua reviewer anonim yang telah membaca, mengoreksi, dan memberi masukan terhadap artikel ini.

\section{DAFTAR PUSTAKA}

Bull, K.S., Montgomery, D., and Kimball, S.L. 2000. Assessment, Evaluation, \& Measurement. Oklahoma: Oklahoma State University.

Callison, D. 2007. Authentic Assessment. Chicago: American Library Association.

Dick, W\& Carey, L. 1990. The Systematic Design of Instruction. Glenview, Illinois London, England: Scat, Foresman \& Company.

Johnson, E. B. 2002. Contextual Teaching and Learning. California: Corwin Press, Inc.

Gebhard, J. G. 2000.Teaching English as a Foreign or Second Language: A Teacher Self-development and Methodology Guide. Michigan: The University of Michigan Press

Kusuma, A. 2011."E-Learning dalam Pembelajaran Bahasa". Lentera Pendidikan, Vol. 14, Nomor 1, 2011.

Rose, C. dan Nicholl, M. J. 2006. Accelerated Learning: Cara Belajar Cepat Abad XXI. Terjemahan oleh Dedy Ahimsa: Purwanto (ed) dari judul asli Accelerated Learning for the $21^{\text {st }}$ Century. Bandung: Penerbit Nuansa.

Sadiman, A. S.1996. Media Pendidikan. Jakarta: Raja Grafindo Persada. 